Beata Pawełczyk-Cnudde*

\title{
STRESS AT WORK: ITS IMPACT ON SUSTAINABLE GROWTH
}

\section{Introduction}

Sustainable economic growth refers to the rate of growth (a positive change in a real output of a country measured by the quantity of goods or services produced) that can be maintained without creating other significant economic problems, especially for future generations (Economics Online).

To continue to grow, the economy requires increase in productive capacity (as well as aggregate demand). Investing in human capital can improve the quality of the labour force, hence its productivity. On the other hand, factors that limit economic growth include poor health and low level of education. People who do not have access to healthcare or education have lower levels of productivity. The economy, therefore, does not fulfil its potential productivity or growth.

The basic unit for economic growth and development is people, regardless of whether we regard them as human capital, a labor force, or human resources. The human being is the engine of change, technological development, innovation, natural resources utilization, and financial capital. And it is people who are at the same time, responsible for, and victims of the current situation in which stress has become excessive at work.

The rapidly increasing speed of business and the expectation of more, better and faster results in the necessity of constant changes. Business and organisational aspects must be regularly adapted and improved in order to face growing competition. Rapid technological developments, which involve the processing of large amounts of information and work reorganisations, causes significant stress at work. Stress has become one of the main causes of disability and inability to work in recent years.

The latest crises faced by the financial sector, the consequences of which spread throughout the global economy, exposed the crucial problem of excessive stress at the workplace. This difficult period was characterised by an increased number of

* Fulcrum Partners bvba (consulting \& training company), Brussels, beata.cnudde@fulcrum-partners.eu 
acquisitions, with the expectation that people would accept new working conditions, often unfavourable for them, and would work more efficiently than before. This need for rapid and dramatic change had not been experienced before and meant that institutions within the financial sector were nearing, or in some cases, had even surpassed, the point of change saturation, everyone felt the impact regardless of whether they were in managerial or specialist positions. Moreover, most of the changes financial companies faced were imposed and unwanted, and as a result caused uncertainty about the future among their employees.

The experience of this period has shown the extent to which businesses in pursuit of profit, neglected the human aspect of the business, despite it being people who form the basis of enterprise development and the economy of the country. In order to maintain business sustainability and growth, financial aspects are crucial, but to attain them, good quality leadership and healthy, well-motivated employees ready to give their best in the long run are indispensable.

The stress that employees struggle with became excessive and started to cause problems that became more and more noticeable to employers. The common symptoms of such an environment saturated with change are: disengagement, apathy, automatic resistance and prevailing stress or even burnout. At the EU level, exposure to stress is considered by current workers (by $53 \%$ of respondents) to be the main workplace health and safety risk ${ }^{1}$. The same survey showed that $27 \%$ of respondents suffered from stress, depression or anxiety caused by or worsened by work quality (during the last 12 months). The main causes of such a situation are: job reorganization and job insecurity, long working hours and increased workload, harassment, and a lack of support.

The situation has become important and in Belgium, for example, the government has taken the necessary measures. Coping with excessive stress and preventing burnout at work became crucial in order to maintain productivity and sustainable employability.

\section{Stress and Its Economic Effects}

\subsection{Research Findings}

The latest financial crisis exposed a large problem: work intensification due to increasing time constraints and a rapid change in the work context. These significant

1 European Commission, Flash Eurobarometer 398, TNS Political \& Social, April 2014. 
changes lead to emerging psychosocial risks (PSR). Such risks, which are linked to the way work is designed, organised and managed, as well as to the economic and social context of work, result in an increased level of stress and can lead to serious deterioration of mental and physical health. When discussing the PSR, it is important, not to confuse these unfavourable conditions with those, where despite an excessive workload and pressure, there is a supportive work environment in which workers are well trained and motivated to perform to the best of their ability ${ }^{2}$.

This situation has given rise to research on job quality and well-being at work as a precondition of business sustainability. A number of studies have confirmed a positive correlation between an employee's well-being at work and work performance ${ }^{3}$. It has been proven that employee work engagement characterized by vigour, dedication, and absorption is vital for both employees and organizations. Engagement is associated with fewer health problems, less absenteeism, lower actual turnover and above all, higher performance ${ }^{4}$.

Health problems and work engagement are considered to be direct outcomes of good or bad job quality. The research published by KU Leuven presented two dimensions of the job quality outcomes:

1. the type of outcome - whether it relates to well-being or performance;

2. the level of outcome - whether it occurs at an employee, organisational or societal level.

According to the presented concept (see Table 1) at the "individual level" a worker realises a certain level of skill development and concentrates rather on his/her career and employment security as well as on the work-life-balance. At the "company level", productivity, workers' mobility and/or absence rates are influenced by the quality of work offered. And on the "macro level", an increase in the quality of the work may result in a higher employment rate as good quality jobs can attract inactive people to the labour market and/or keep older workers at work.

Van der Klink ${ }^{6}$ pointed out that work and health have now changed places. He explained that in the past, work was the determinant and health was a state that people

2 Guide to the prevention of psychosocial risks at work, "Employment, Labour and Social Dialogue" (ELSD), Namur 2013, available at: www.employment.belgium.be

3 G. Reijseger, W. Peeters, T. Taris, W. Schaufeli, From Motivation to Activation: Why Engaged Workers are Better Performers, (2017), p. 118; published on-line by Springer Science Business Media New York on 10 March 2016.

4 G. Reijseger, W. Peeters, T. Taris, W. Schaufeli, From Motivation to..., op.cit., p. 123.

5 T. Vandenbrande, S. Vandekerckhove, P. Vendramin, G. Valenduc, R. Huys, R. Van Hootegem, I. Hansez, C. Vanroelen, V. Puig-Barrachina, K. Bosmans, \& H. De Witte, Quality of Work and employment in Belgium, KU Leuven - Research Institute for Work and Society, revised version, February 2013, p. 8.

6 J.J.L. Van der Klink, U. Bültmann, A. Burdorf, W.B. Schaufeli, F.R.H. Zijlstra, F.I. Abma, S. Brouwer, G.J. Van der Wilt, Sustainable employability - definition, conceptualization, and implications: A perspective based on the capability approach, Discussion Paper, Scand J Work Environ Health 2016, p. 72. 
strove to maintain despite the burden of work. Currently, health is the resource, and employment or work is the state that people want to preserve, sometimes even despite the burden of suboptimal health. Nowadays employees are no longer a "passive performer of predefined tasks" (as it was in industrial labour times), but an "autonomous and responsible entrepreneur in his or her work, who proactively sets his/her own goals and makes his/her own choices and (shared) decisions" (times of post-industrial labour - mainly services) $)^{7}$. For many people work became important and crucial for fulfilling their ambitions and personal goals and good health is now a condition or resource to achieve them.

\section{Table 1}

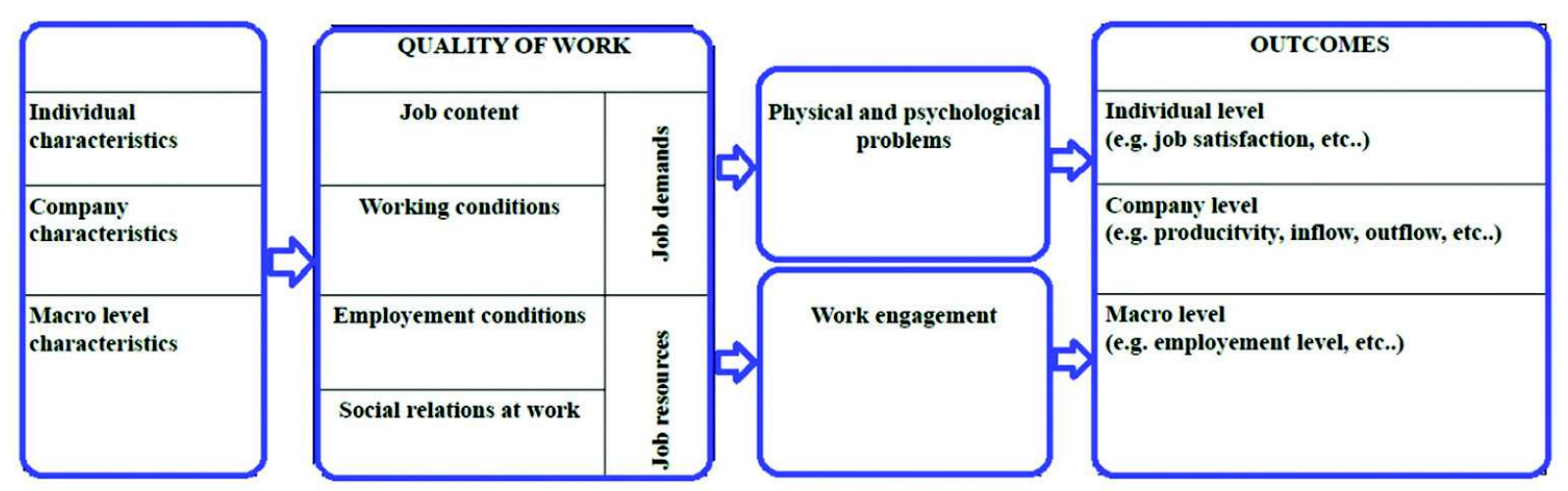

Source: KU Leuven, "Quality of Work and Employment in Belgium” 2013.

Quite recently, the World Health Organization (WHO) has emphasized the special importance of mental health as "a state of well-being in which every individual realizes his or her own potential, can cope with the normal stresses of life, can work productively and fruitfully, and is able to make a contribution to his or her community" ${ }^{8}$, and according to the WHO stress has become the leading cause of disability and inability to work in recent years.

Bakker and Schaufeli ${ }^{9}$ introduced the idea distinguishing different impact of the working conditions on the employee: negative (having consequences in health impairment) and positive (increased motivation). They suggested that job demands may exhaust an employee's mental and physical resources and may, therefore, lead to the depletion of energy and to health problems. On the other hand, the presence

ibidem, p. 73.

8 World Health Organisation, Health Impact of Psychosocial Hazards at Work: An Overview, Geneva 2010

9 A.B. Bakker, W.B. Schaufeli, M.P. Leiter \& T.W. Taris, Work engagement: An emerging concept in occupational health psychology, "Work \& Stress" 2008, vol. 22, no. 3, Taylor \& Francis, pp. 187-200. 
of adequate job resources reduces job demands, fosters goal accomplishment and stimulates personal growth and development. In turn, this may lead to a stronger dedication to one's work (engagement) and thus to a lower intention of leaving the organisation.

Other findings indicated that work engagement and open-mindedness relate positively with each other. Open-mindedness is positively related to employees taking more initiative, helping colleagues, and doing their tasks with greater effectiveness ${ }^{10}$. "Facilitating an open mind at work by stimulating work engagement promotes workers' mental health and optimal functioning" ${ }^{11}$. Thus, investing in an engaged workforce means investing in a healthy performing organization.

Lawson and Price ${ }^{12}$ recall the necessity of meeting the values at work. If people believe in the overall purpose, they will be happy to adapt their individual behaviour to serve that purpose, but they will suffer from cognitive dissonance if they do not. They supported this opinion with the findings of social psychologist Festinger from Stanford who published in 1957 his theory of cognitive dissonance and the distressing mental state which arises when people find that their beliefs are inconsistent with their actions.

Jonathan Holslag in his book "The Strength of Paradise" argues for a stronger focus on values that are essential to human existence. He claims that values such as meaning, recognition, and security can be met in the workplace ${ }^{13}$. And if the values are met, people are more likely to be capable and willing to continue to work.

Amartya Sen, an Indian economist and philosopher, and winner of the 1998 Nobel Prize, presented a model where an individual's sustainable employability is determined by how he or she succeeds in converting resources into capabilities, and subsequently into work functioning in such a way that values like security, recognition and meaning are met. He argues that at present, workers require a wider range of valued outcomes from their work rather than an income alone. For these workers, work - and in line with that, employment and employability - is sustainable if it can provide the broader values ${ }^{14}$. The lack of them is a frequent cause of stress and even burnout (discussed in chapter 3.1.), which results in long-term absences.

10 G. Reijseger, W. Peeters, T. Taris, W. Schaufeli, From Motivation to..., op.cit., p. 121.

11 A.B. Bakker et al., Work engagement..., op.cit., pp. 187-200.

12 E. Lawson and C. Price, The psychology of change management, “The McKinsey Quarterly" 2003, “The Value in Organizations", available online: https://www.mckinsey.com/business-functions/organization/ our-insights/the-psychology-of-change-management

13 J. Holslag De Kracht, Van het Paradijs, [The Strength of Paradise], De Bezige Bij Amsterdam, Antwerp 2014, pp. 310-490.

14 J.J.L. Van der Klink et al., Sustainable employability..., op.cit., p. 73. 


\subsection{Costs and Advantages}

Much research has been carried out to answer the question over why organizations should focus on investing in stress prevention and the overall well-being of their employees instead of keeping them merely satisfied.

The European Agency for Safety and Health at Work has adopted this definition: "work-related stress is experienced when the demands of the work environment exceed the workers' ability to cope with (or control) them". According to EASHW, a low level of safety and health cost companies money. The Agency indicated that in Europe the cost of mental disorders is around 240 billion euros per year ${ }^{15}$. According to its findings, without the introduction of any preventative measures against stress and psychosocial risks at work, not only one in four European workers would be confronted with occupational stress, but this stress would also have a negative impact on their health and well-being.

The analysis of the European Working Conditions Survey ${ }^{16}$ confirmed the relationship between the well-being and health of workers and the nature and quality of their job: general health (both mental and physical) is correlated with sustainable work. And work-related health risks are associated with a low score for sustainability. It is important, therefore, to ensure people are healthy and have work.

French economist Christian Trontin ${ }^{17}$, in his macroeconomic approach crossed data of economic activity and data from statistical surveys, such as epidemiological studies, and estimated that 1 to $1.4 \%$ of the working population in France in 2000 were affected by a stress-related pathology (cardiovascular disease and depression). The cost associated with work stress represented at that time, 10 to $20 \%$ of the costs classified by social security as "accidents at work and occupational diseases". This study clearly showed how the problem of health, of relatively low prevalence, can represent a significant social cost for the country.

According to Occupational Safety and Health Administration (OSHA) a dysfunctional prevention policy results in a cost that on average - depending on the study referred to - varies between 2 and 3.5\% of GDP, the introduction of good occupational safety and health (OSH) pays off. Businesses with higher safety and health standards are more successful and more sustainable. The studies carried out by the International Social Security Association (ISSA) estimate that for every euro invested

15 EASHW 2015, Second European Survey of Enterprises on New and Emerging Risks (ESENER-2), p. 18.

16 European Working Conditions Survey, Eurofund 2016, available online: http://www.eurofound.europa. eu/european-working-conditionssurveys-ewcs

17 C. Trontin, Coûts du stress: éléments d'appréciation des enjeux économiques, Information presented during the Colloque CHP in Liège Travail et Stress: la loi sur le Bien-Etre, 10 ans déjà... et après?, Liège 2006. 
in OSH, there is a return of 2.2 euros and that the cost-benefit ratio of improving safety and health is favourable (see Table 2). Everyone from individual workers to national health systems loses out when OSH is neglected.

Table 2

\begin{tabular}{|c|c|c|c|}
\hline \multicolumn{4}{|c|}{ PREVENTION BALANCE SHEET } \\
\hline \multicolumn{2}{|l|}{$\begin{array}{l}\text { Occupational safety and health costs } \\
\text { per employee per year (in EUR) }\end{array}$} & \multicolumn{2}{|l|}{$\begin{array}{l}\text { Occupational safety and health benefits } \\
\text { per employee per year (in EUR) }\end{array}$} \\
\hline Personal protective equipment & 159 & Cost savings through prevention of disruptions & 506 \\
\hline $\begin{array}{l}\text { Guidance on safety technology and company } \\
\text { medical support }\end{array}$ & 251 & $\begin{array}{l}\text { Cost savings through prevention of wastage and } \\
\text { reduction of time spent for catching up after disruptons }\end{array}$ & 386 \\
\hline Specific prevention training measures & 142 & $\begin{array}{l}\text { Added value generated by increased employee } \\
\text { motivation and satisfaction }\end{array}$ & 561 \\
\hline Preventive medical check-ups & 56 & $\begin{array}{l}\text { Added value generated by sustained focus } \\
\text { on quality and better quality of products }\end{array}$ & 400 \\
\hline Organizational costs & 235 & Added value generated by product innovations & 229 \\
\hline Investment costs & 241 & Added value generated by better corporate image & 563 \\
\hline Start-up costs & 116 & & \\
\hline Total costs & 1,200 & Total benefits & 2,645 \\
\hline \multicolumn{4}{|c|}{ PREVENTION NET BENEFITS = 1,445 } \\
\hline
\end{tabular}

Source: ISSA Final Report 2013 "Calculating the international return on prevention for companies: costs and benefits of investments in occupational safety and health".

The ISSA 2013 Report presents the main economic advantages of good OSH:

1. for businesses large and small, it:

- improves workers' productivity;

- cuts down on absenteeism;

- reduces compensation payments;

- meets the requirements of public and private sector contractors.

2. at a national level, it:

- improves productivity through less sickness absence;

- cuts healthcare costs;

- keeps older workers in employment;

- stimulates more efficient working methods and technologies;

- reduces the number of people who have to cut their hours to care for a family member. 
Despite the benefits of preventing stress at work, many countries of the European Union have not introduced action plans to act accordingly (see Table 3).

\section{Table 3}

\section{Does your establishment have an action plan to prevent work-related stress?}

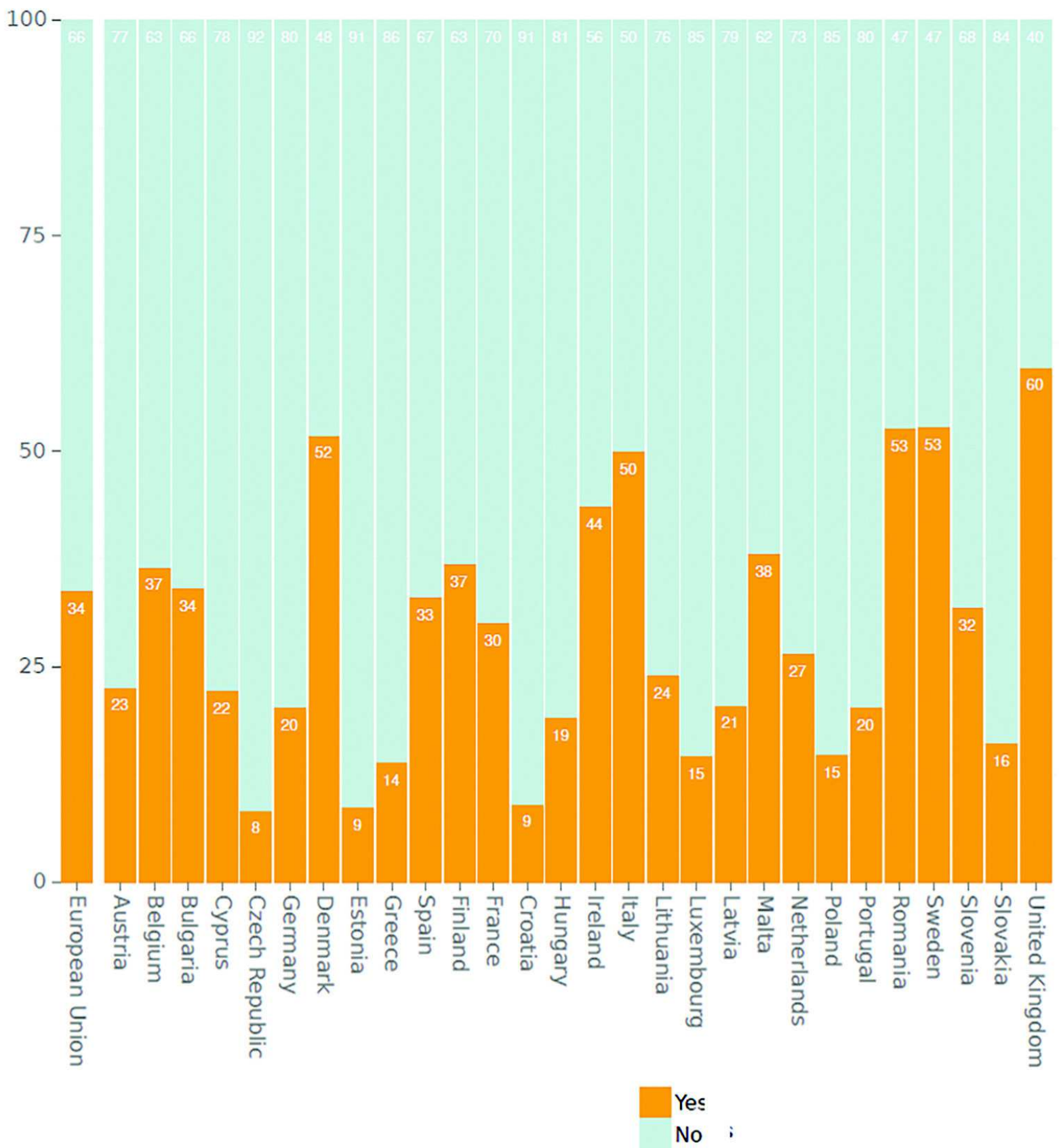

Source: EU-OSHA - European Agency for Safety and Health at Work, data online Nov 2017 : https://osha.europa.eu/en/surveys-and-statistics-osh/esener 


\section{The Belgian Experience}

\subsection{Stress and Burnout}

Long-term, unresolvable stress at work often results in burnout. According to Christina Maslach ${ }^{18}$, burnout is a syndrome of physical and emotional exhaustion, which results in the development of negative self-esteem and negative attitude to work, as well as a decline in interest in the problems of others. According to her, burnout is not due to a problem with an individual person, but due to problems of the social environment in which they work. The responsibility is, therefore, on the side of the employer. An effective response to stress and burnout must include prevention rather than treatment.

The main causes of burnout are:

1. Excessive work overload;

2. A lack of control over what we do / loss of autonomy;

3. A lack of adequate rewards for work - the lack of recognition;

4. The breakdown of the community - the loss of good contact with colleagues. The fast pace of work and the growing frustration of employees leads to tensions and conflicts;

5. Unfair treatment - especially regarding salary levels, work load, bending the rules by some at the expense of others, unfair promotions;

6. A conflict of values ("soul erosion").

In Belgium, the most frequent cause of excessive stress and burnout is the workload (58\%). Other common constraints are: time pressure (41\%), organizational change (38\%), conflict in the workplace (37\%) and difficulties with work and private life balance $(30 \%)^{19}$.

According to the White Paper published by Secure ${ }^{20}$ in 2015, in large organizations (500 or more workers), HR managers reported that $2.7 \%$ of their employees were absent due to burnout in the last 12 months. Similarly, 7.7\% of workers were, according to their employers, in a pre-phase of burnout, which entailed a high risk of absenteeism. In case of SMEs the number of workers absent due to burnout was much lower: $1.6 \%$.

18 Ch. Maslach, M.P. Leiter, Prawda o wypaleniu zawodowym, PWN, Warszawa 2011, pp. 6-36.

19 I. Hansez, P. Mairiaux, P. Firket et al., Recherche sur le Burnout au sein de la population active belge: rapport final, Brussels 2012, p. 95.

20 Securex provides services in human resources for all kinds of business in Belgium. 
The consequences of excessive stress are not negligible. Securex reported that stress accounted for more than one-third of sick-leave days and cost the employer more than 3,750 euros per worker each year for various stress problems, and up to 20,000 euros per case of burnout.

The same studies by Securex showed, however. that positive changes introduced into the company in relation to the organization, the degree of work autonomy, teamwork and good atmosphere, were able to reduce tensions by $30 \%$.

The indirect costs related to reorganization of work, temporary replacement and overtime and for example, the drop-in quality and performance, are not to be disregarded. The excess of stress increased the number of voluntary departures which could negatively impact the duration of the employees' career. Employability has thus become a critical condition both for the sustainability of employees' careers and for organizations, which for their performance depend on the employability of their workforce.

\subsection{Legal Regulations}

Belgium has a long tradition of research in the field of working conditions, job stress and health outcomes. The Belgian Science Policy as well as the Belgian Federal Public Service Employment, Labour and Social Dialogue and the European Social Fund have extensively supported research in this field, either in analysing working conditions and their impact on well-being at work, or in developing methodologies and instruments to help companies in designing prevention and intervention strategies.

In 2011, the "L'Institut National d'Assurance Maladie-Invalidite" (INAMI) emphasized that the number of disabled people had increased by $72 \%$ over the last 10 years, one of the causes being attributed to mental problems and stress at work.

The studies carried out in Belgium at the request of the federal Ministry of Employment by the scientists led by Professor Hansez showed that the number of employees suffering from stress increased every year. In 2012, the number of people unable to work for more than 1 year amounted to 300,000 workers and employees (an increase of $33 \%$ over 10 years), including mental disorders (34\%) and musculoskeletal disorders (e.g. low back pain and neck muscle problems) (29\%). The employees reported mental problems such as fatigue, sleeping problems and psychosomatic symptoms, e.g. headaches and gastrointestinal complaints caused by their work. According to the studies, there were 19,000 confirmed cases of burnout in Belgium in 2010 ${ }^{21}$.

21 I. Hansez et al., Recherche sur le..., op.cit., p. 104. 
In Belgium, a legal framework supporting a strong policy in respect of working conditions and well-being at work was established already by:

- the law of 4 August 1996 on the well-being of workers in the performance of their work and

- the law of 11 June 2002 relating to protection from violence, moral harassment (bullying) and sexual harassment at the workplace;

- the amendments introduced in 2007 (law of 10 January 2007 and 6 February 2007). The increasing level of stress among employees, often leading to a long-term absenteeism (or presenteeism when workers turn up for work when sick and unable to function effectively) affecting productivity and jeopardizing continuity within the organization, was the main cause of adopting a new law in Belgium in 2014 to protect employees against stress and burnout. Under this new law, passed on 28 February 2014, and which came into force on 1 September 2014, employees have been extensively protected not only against violence, bullying and sexual harassment at work but also against psychosocial risks. This is because these risks can have an impact on both the individual (depression, burnout) and collective levels (conflicts, negative atmosphere at work), and result in more work accidents, lower production, and declining quality of work output.

According to the Belgian National Strategy for Well-being at Work ${ }^{22}$, the employment policy must focus on people. This means that it should prioritize the improvement of the quality of life and the health and safety of workers in their daily working lives. This protection of the employees at work has in turn a positive impact on the productivity of the companies and the national economy.

\section{Conclusion}

Over the last decades, substantial evolution has taken place in the workplace, which has important implications for the nature of careers. Careers have become increasingly insecure, both from an organizational and an individual viewpoint. Many companies undergo constant changes and development, and employees must be increasingly flexible in order to meet the demands of the job market and their businesses.

22 The Belgian National Strategy for Well-being at Work 2016-2020, proposed by the Minister of Employment: Strategic and operational objectives, p. 3. 
The perception of stress at work may be misinterpreted, though, as for many employers the increase in stress and related health problems is the price to be paid for a maximum increase in performance of the production tool. Such an increase could be sustained but only over a limited period of time, in the face of a sudden crisis, emergency or a risk. The studies ${ }^{23}$ confirmed, however, that in the long term it would end up wearing out not only the individual but also the organisation.

The lack of an effective approach to the human capital dimension can adversely affect the productivity of a given company, as the predominant stress causes conflicts, dissatisfaction, different ailments of employees and absences (short but also long-term leaves). In case a problem is widespread in the country, the neglected situation, in the long term may consequently affect the whole economy.

Employees experience stress when the demands of their job are excessive and greater than their capacity to cope with them. In addition to mental health problems, workers suffering from prolonged stress can go on to develop serious physical health problems such as cardiovascular diseases or musculoskeletal problems. For organisations, the negative effects of excessive stress at work mean a drop in overall business performance, increased absenteeism and presenteeism and increased accident and injury rates. Absences tend to be longer than those arising from other causes and work-related stress may contribute to increased rates of early retirement. Estimates of the cost to businesses and society are significant and run into millions of euros at a national level.

In general, stress plays an important role for society as a whole. Health of employees largely determines how long a person can and will want to pursue their career. In fact, less tense workers tend to want to stay active longer. A study conducted by Securex in 2013 on the sustainable employability of Belgian workers concluded that on average, persons want to continue working until they are 61 years old, while their colleagues suffering from various stress-related problems have an average career to the age of 58 years. In a context of increasing ageing, the management of stressors can, therefore, contribute to keeping workers longer in the labour market. In this regard, the role of mental health surpasses other aspects that determine sustainable employability.

Employees will have to work longer and thus will need to keep their employability also at older ages. In the context of an ageing population and the need of the longterm financial stability of social protection systems, the concept of sustainable work

23 I. Hansez \& V. De Keyser, Du diagnostic des risques psychosociaux à la gestion organisationnelle du stress. [in:] M. Neboit \& M. Vezina, Santé au travail et santé psychique, chapter 14, Toulouse, France 2002, pp. 189-206. 
is under the spotlight. Many countries have already implemented policies aimed at postponing retirement. It is important to ensure that workers are able and willing to work longer. Investing in employability of the ageing workforce requires, however. a shift in mind-sets. As underlined by the Eurofound ${ }^{24}$, it means that working conditions in a broad sense (including working time patterns, work organisation, work environment and exposure to physical and psychosocial risks) need to be adapted to enable a better balance between paid work and other social activities, as well as to enhance well-being and promote good health.

As discussed before, it is vital not only to business but also to the economy that workplaces provide encouragement, opportunity and support for workers to develop and use their skills and capacities effectively. Healthy, highly skilled and highly productive workplaces enable people to perform at their best at all ages. In such improved circumstances, the increased employability especially in the face of constant changes and competition, may help to foster innovation and the adoption of new technologies. Finally, it may lead to improved economic performance and sustainable growth.

\section{Appendix: Human Side of a Business: A Case Study ${ }^{25}$}

\section{Presentation of a Case}

In order to illustrate the problem of excessive stress at work, I present in this annex a case that took place in the years 2008-2010 during the above-mentioned financial crisis. It is a good example of the great pressure and stress imposed on employees during the time of the ongoing business changes in one of the financial companies based in Brussels, called here ABC-FI. This stress may have been avoided if the right measures and proper management had been applied.

In 2008 ABC-FI belonged to ABC-Group (ABC Bank, ABC Financial Investments (ABC-FI) and $\mathrm{ABC}$ Insurance). The analysis presented here focuses on the situation observed in one of the departments of ABC-FI (called here: CRUCIAL DEPARTMENT - CD). The core business of ABC-FI was financial investments

24 Eurofound, Working time patterns for sustainable work, Publications Office of the European Union, Luxembourg 2017, pp. 61-64.

25 The present case study is based on the experience and research of the author and was part of the thesis Change management - approach including business and human dimensions presented at the Université Libre de Bruxelles (ULB) in January 2014. 
executed around the world, therefore ABC-FI had its premises located in different countries with employees coming from different cultural backgrounds. It was a multicultural company hiring employees of different origins (mainly Flemish and Welsh but also other Europeans, Asians and Muslims).

In $2007 \mathrm{ABC}-\mathrm{FI}$ took over foreign financial company X based in European country $\mathrm{XN}$. This led to many organisational changes and many employees felt frustrated and highly stressed. The atmosphere was tense and it became necessary to take efficient steps and measures. After just one year, the overall situation started to improve, and in 2008, as a result of all the improvement measures and efforts of all the employees, $\mathrm{ABC}$-FI was positively evaluated by an external auditor and received a better rating by the International Rating Agencies.

However, in 2008 the financial crisis continued to spread worldwide and came from the United States to Europe. ABC-FI, although itself financially "healthy", belonged to big financial "ABC-Group", which announced critical problems in its Bank. As a consequence of these financial problems and a loss of reputation on the market, in 2009 the whole "ABC-Group" was bought by foreign financial group AAS.

The overtaken ABC-FI faced important challenges:

- legal: ownership had changed;

- general business challenge: AAS wanted to take over all the tasks of the CRUCIAL DEPARTMENT of ABC-FI and leave just a small area of fully automated tasks in Brussels; the top management of ABC-FI decided to prove that the process in Brussels performed better than in AAS and hence should stay in Brussels;

- organisational: the structure and culture were to be adapted to AAS' needs;

- internal systems were to be changed and adapted to AAS - internal migration;

- vis-a-vis managers and employees: to keep motivation in the relatively unstable situation, under huge pressure, increased workload, management changes, etc.;

- cost cutting: training, salary rises, and bonuses were suspended.

$\mathrm{ABC}$-FI was faced with a clear problem relating to the business acquisition: uncertainty about the future and necessity of changes that were imposed and unwanted. The changes were initially regarded both by managers and employees as a threat, constraint and difficulty, provoking such reactions as anxiety and resistance. The status-quo had been violated. The communication between HR and employees was suspended. Neither the top management nor HR was sure about the outcome of their negotiations with AAS concerning:

- which part of the business would be maintained in Brussels;

- organisational re-structure - new departments, new managers;

- how many employees would be needed for the new structure - ABC-FI officially wanted to keep as many of the posts as possible; 
- hence, they could not communicate any direct and clear information; they tried, however, to calm down the tense situation by ensuring that jobs would be maintained.

The top management informed the staff that in order to keep their jobs, the company needed to prove that the tasks were performed much better in Brussels than by the same department in AAS. Huge pressure was imposed on all of the employees, work was supposed to be done faster and be of better quality than in AAS. At the same time, the line and middle managers were supposed to maintain a positive atmosphere and high motivation level within the teams. All financial incentives, however, were cut at that time. The line and middle managers were left with their own soft skills, without any support, training or coaching.

The stress and uncertainty about the future situation caused escalation of conflicts between the managers of different teams and then between the employees. There was no longer cooperation but competition instead. Suddenly the differences in origin and managerial levels started to be important and an internal political struggle began.

At the same time the top management started a restructuring process in order to meet the demands of AAS. The organizational structure became more complicated and more hierarchical. The managers were shuffled and located not only in Brussels but also abroad, e.g. London and Paris, where AAS' headquarters was located. This led to a more complex decision-making process.

The organisational culture had changed. From a relatively informal and direct structure it became very hierarchical with the highest management levels located abroad. The decision-making process became much longer. ABC-FI was a multicultural organisation with its own style of management.

Before the acquisition, the cross-cultural management was based on working in teams and collaboration also across hierarchical levels. Allocation of roles within the team was quite clearly defined and people took greater responsibility for their specific tasks (autonomy). This approach was quite normal for a country of factionalism and regionalism, such as Belgium. The organizational culture of ABC-FI was based on direct contacts and relative openness that made a decision-making procedure relatively fast, which is crucial in the financial world.

Due to the acquisition, however, the management style changed and adapted to that of AAS'. It became more authoritarian and hierarchical. Managerial positions and the corresponding power were now clearly defined. Decisions were taken only at senior levels and passed down the chain to lower management just for implementation. Hence it had no necessary team-building elements. Additionally, the working contacts between the middle/line managers of ABC-FI and those in AAS became very formal, often through their secretaries. 
On top of all the internal problems there was one very important challenge: to keep the trust of clients and shareholders.

The consequences of these changes were the following:

- the top management lost its close connection with the middle and line managers - as they were busy with strategic issues;

- communication was basically limited to present the new organigrams;

- the middle and in particular line managers were left without any support - neither from the HR nor the top management;

- the employees (including the management) worked under enormous pressure with an increased workload;

- many changes were planned to be executed at the same time, and thus the situation was very stressful and even chaotic;

- it was already the second reorganization in the relatively short period of time (2-3 years) and some of the employees started to feel tired, frustrated, overstressed, burnt-out, resistant to changes;

- increased absenteeism.

It was quite clear that the takeover by another bank surprised everyone and there was a lack of an efficient change management plan. The right and effective change management plan should have been prepared and then implemented by the new merged company ABC-FI-AAS.

\section{Findings}

The case of ABC-FI showed that many essential aspects were missing, especially as concerns the human part of the process. The top management did not assess the potential risks and their impact on motivation and resistance, when imposing a sense of urgency and pressure of the changes on the business side. One can permanently change and update systems or procedures and they will continue to work and be more efficient, but the organization consists not only of systems and buildings but also of people and human relationships.

Executives often forget that change does not happen instantaneously just because there was an announcement, a kick-off meeting or even a go-live date, change concerns individuals, not simply IT systems or organigrams. In addition, employees do not change simply because they receive an email or attend a meeting with an executive ${ }^{26}$.

26 Prosci change management tutorial (2013), available on-line: http://www.change-management.com/ tutorial-7-principles-mod8.htm 
In the times of globalization and the internet, many organizations, such as ABC-FI, represent a multinational and multicultural workforce. In case of acquisition, such companies are challenged not only with the internal culture but with many cultural values that vary from person to person. The managers face an important challenge and they must be prepared to deal with potential or real conflicts arising from cultural differences (national cultures, company cultures, etc.).

ABC-FI underwent many organizational changes during a relatively short period of time. The first changes had not yet been completed (related to the takeover of company $\mathrm{X}$ ) when the new, even more significant changes had to be implemented (the acquisition). In order to avoid quite high costs related to the absence of the employees, due to high stress or burnout, ABC-FI might have prepared and introduced an organisational solution that would have prevented the situation. This aspect was absolutely not taken into account. As a consequence, many dissatisfied persons left the company. Those that stayed had to adapt to the new circumstances but paid an unnecessary cost in the form of anxiety, stress, frustration and even burnout. This obviously had a negative impact on the efficient implementation of the necessary changes, hence on the business itself. It is not beneficial to neglect the human aspects of the changes as, in the end, such an approach backfires on the performance of the entire company.

\section{Conclusion}

During the described period, the situation at ABC-FI was quite serious due to a high staff turnover, long-term absences and other unforeseen costs. After approximately two years, the situation in the company has stabilized.

Thanks to the new law, which came into force in September 2014, as well as to a wide-ranging campaign in Belgium, the employer's awareness has increased as to creating the right conditions for work and the employee's career development.

However, as employees are extensively protected now, companies more and more often hire contract-agents. And already a significant increase in work load and stress level in this group has been observed... 


\section{Bibliography}

Bakker, A.B., Schaufeli, W.B., Leiter, M.P., \& Taris, T.W., Work engagement: An emerging concept in occupational health psychology, "Work \& Stress" 2008, vol. 22, no. 3, Taylor \& Francis.

De Keyser V. \&Hansez I., Du diagnostic des risques psychosociaux à la gestion organisationnelle du stress, Toulouse 2002.

EASHW 2015, Second European Survey of Enterprises on New and Emerging Risks (ESENER-2).

Employment, Labour and Social Dialogue (ELSD) 2013, Guide to the prevention of psychosocial risks at work, Namur 2013, available at: www.employment.belgium.be

Eurofound, Working time patterns for sustainable work, Publications Office of the European Union, Luxembourg 2017.

European Commission, Flash Eurobarometer 398, TNS Political \& Social, April 2014.

Festinger L., A Theory of Cognitive Dissonance, Stanford University Press 1957.

Hansez I., Mairiaux P., Firket P. et al., Recherche sur le Burnout au sein de la population active belge: rapport final, Brussels 2012.

Holslag J. De Kracht van het Paradijs [The Strength of Paradise], De Bezige Bij Amsterdam, Antwerp 2014.

International Labour Office, A Skilled Workforce for Strong, Sustainable and Balanced Growth, Geneva, November 2010.

ISSA Final Report 2013, Calculating the international return on prevention for companies: Costs and benefits of investments in occupational safety and health, 2013.

Hansez, I., \&De Keyser, V., Du diagnostic des risques psychosociaux à la gestion organisationnelle du stress, [in:] M. Neboit \& M. Vezina, Santé au travail et santé psychique, chapter 14, Toulouse, France 2002.

Lawson, E. and Price, C., The psychology of change management, "The Value in Organizations. The McKinsey Quarterly" 2003.

Maslach Ch., Leiter M.P., Prawda o wypaleniu zawodowym, PWN, Warszawa 2011.

OECD, World Bank, Enhancing employability - report prepared for the G20 Employment Working Group with inputs from The International Monetary Fund, 2016.

OSHA, available online: https://osha.europa.eu/en/topics

Peeters, M.C.W., Montgomery, A.J., Bakker, A.B. \&Schaufeli, W.B., Balancing work and home: How job and home demands are related to Burnout, "International Journal of Stress Management” 2005, no. 12.

Prosci change management tutorial 2013, available online:

http://www.change-management.com/tutorial-7-principles-mod8.htm 
Reijseger G., Peeters W., Taris T., Schaufeli W. (2017), "From Motivation to Activation: Why Engaged Workers are Better Performers", published on-line: 10 March 2016 by Springer Science Business Media, New York 2016.

Sen, Amartya, Commodities and Capabilities, $2^{\text {nd }}$ ed., Oxford University Press, Delhi, New York 1999.

The Belgian National Strategy for Well-being at Work 2016-2020 as proposed by the Minister of Employment: Strategic and operational objectives.

Trontin, C., Coûts du stress: éléments d'appréciation des enjeux économiques, Paper presented during the Colloque CHP in Liège Travail et Stress: la loi sur le Bien-Etre, 10 ans déjà... et après?”, Liège 2006.

United Nations, World Population Prospects: The 2008 revision, Department of Economic and Social Affairs, New York 2008.

Van der Klink J.J.L., Bültmann U, Burdorf A, Schaufeli W.B., Zijlstra F.R.H., Abma F.I., Brouwer S, van der Wilt G.J., Sustainable employability - definition, conceptualization, and implications: A perspective based on the capability approach, Discussion Paper, Scand J Work Environ Health 2016.

Vandenbrande T., Vandekerckhove S., Vendramin P., Valenduc G., Huys R., Van Hootegem R., Hansez I., Vanroelen C., Puig-Barrachina V., Bosmans K., \& De Witte H., Quality of Work and employment in Belgium, KU Leuven - Research Institute for Work and Society, revised version, February 2013.

World Health Organisation, Health Impact of Psychosocial Hazards at Work: An Overview, Geneva 2010.

\section{Stress at Work: Its Impact on Sustainable Growth}

This paper aims to show the importance of stress at work for the economy. Stress, which until recently was considered mainly in psychological or social terms, has a direct impact on human capital and labour, which are the basic factors of economic growth (as well as natural resources, technology, physical and financial capitals).

The quality and quantity of human capital directly affects the growth of the economy. An increase in investment in human capital can improve the quality of the labour force, hence its productivity. On the other hand, factors that limit economic growth include: poor health and low level of education. People who do not have access to healthcare or education have lower levels of productivity. The economy, therefore, does not fulfil its potential productivity or growth.

Stress negatively contributes to changes of these factors. It has become one of the main causes of disability and inability to work in recent years. 
The first part describes the overall situation in which stress has become an issue for companies and the economy.

In the second part I present the different research findings that demonstrate how the meaning and importance of work, and workplace conditions, have evolved. I refer, as well, to quantitative findings proving that companies should invest in preventing stress at work as excessive stress affects performance and productivity.

The third part briefly portrays the example of Belgium, where the problem of stress and its economic consequences have been quite thoroughly investigated. The costs of excessive stress were regarded as undue, and as a result, Belgium adopted a law protecting employees against stress and burnout at work. Under this law, employers are obliged to introduce specific internal rules and preventative measures.

Based on the Belgian experience, I provide several arguments demonstrating that improving the workplace by mitigating stress levels is beneficial not only for a company itself but for the economy in general. It impacts positively human capital, employability, leads to improved productivity, and in the end, contributes to sustainable economic growth.

At the end of the paper, in an annex, I present a case illustrating the problem of excessive stress at work. It is an example of the great pressure and stress imposed on employees during the time of the ongoing business changes in one of the financial companies based in Brussels.

The purpose of this article, however, is not to exhaust the topic of the impact of stress on economy, but rather to induce discussion on the magnitude and importance of this problem.

Keywords: stress at work, burnout, employability, sustainable growth, healthy workplace, cost of stress for the economy

\section{L'effet du stress au travail sur la croissance durable}

L'article vise à démontrer l'importance du stress au travail pour l'économie. Le stress, considéré jusqu'il y a peu surtout sur le plan psychologique ou social, a un impact direct sur le capital humain et la main d'œuvre, facteurs fondamentaux de la croissance économique (ainsi que les ressources naturelles, la technologie, le capital productif et financier). 
La qualité et la quantité de capital humain ont un impact direct sur la croissance économique. L'investissement accru dans le capital humain peut améliorer la qualité de la main-d'œuvre et donc sa productivité. D'un autre côté, les facteurs limitant la croissance économique sont: la mauvaise santé et le faible niveau d'éducation. Les personnes n'ayant pas accès aux soins de santé ou à l'éducation ont un niveau de productivité inférieur. Par conséquent, l'économie n’atteint pas son potentiel en termes de productivité et de croissance.

Le stress a un effet négatif sur ces facteurs. Au cours des dernières années il est devenu l'une des causes principales d'incapacité de travail, en raison de problèmes de santé psychologique et physique des employés.

Le premier chapitre donne un aperçu de la situation générale où le stress est devenu un problème pour les entreprises et l'économie.

Dans le deuxième chapitre, je présente les résultats de différentes recherches montrant comment ont changé l'intérêt et l'importance du travail et des conditions de travail. Je fais également référence aux résultats quantitatifs qui confirment la nécessité pour les entreprises d'investir dans la prévention du stress au travail, car un stress excessif affecte l'efficacité et la productivité.

Dans le troisième chapitre, je présente l'exemple de la Belgique, où le problème du stress et de ses conséquences économiques ont fait l'objet de recherches approfondies. Les coûts du stress démesuré étant considérés comme excessifs, la Belgique a adopté une loi protégeant les travailleurs du stress sur le lieu de travail et du burnout. En vertu de cette loi, les employeurs sont tenus d'introduire des règlements internes spécifiques et des mesures préventives nécessaires.

En me basant sur l'expérience belge je présente plusieurs arguments confirmant que le fait d'améliorer les conditions de travail en réduisant le stress est bénéfique non seulement pour l'entreprise elle-même, mais aussi pour l'économie. Cela a un impact positif sur le capital humain, la capacité à créer des emplois, à améliorer la productivité et, en fin de compte, à contribuer à une croissance économique durable.

À la fin de l'article je présente en annexe un exemple du problème du stress excessif au travail. Il s'agit d'un cas d'une des sociétés financières basées à Bruxelles où les employés ont subi une pression énorme pendant la crise financière; depuis lors les changements sont apportés dans l'entreprise pour améliorer les conditions de travail.

Cependant le but de cet article n'est pas d'épuiser le sujet de l'impact du stress sur l'économie, mais plutôt d'engager une discussion sur la taille et l'importance de ce problème. 
Mots-clés: stress au travail, burnout, employabilité, croissance durable, environnement de travail sain, coût du stress pour léconomie

\section{Стресс на работе и его влияние на устойчивость трудоустраиваемости и устойчивый рост}

В статье утверждается, что в последние годы стресс является одним из основных факторов инвалидности и неспособности к труду. Постоянные изменения в деловом мире и растущие соперничество приводят к тому, что сотрудники подвергаются значительному давлению. Как следствие, чрезмерный стресс и различные проблемы со здоровьем влияют на работу компаний и угрожают трудоустройству. В статье приводятся аргументы, подтверждающие, что инвестирование в здоровое рабочее место выгодно для экономики, поскольку оно положительно влияет на производительность и трудоустройство, ведет к улучшению экономических показателей и, в конечном итоге, способствует устойчивому росту.

Ключевые слова: стресс на работе; выгорание; устойчивое трудоустройство; устойчивый рост; здоровое рабочее место; экономические затраты, связанные со стрессом 